\title{
Removal of Phosphate from Synthetic Aqueous Solution by Adsorption with Dolomite from Padalarang
}

\author{
Fadjari Lucia Nugroho, Lili Mulyatna \& Anggi Doli Wiranata Situmeang \\ Department of Environmental Engineering, Pasundan University \\ Jl. Dr. Setiabudi No. 193, Bandung 40153, Indonesia \\ Email: lnugroho@melsa.net.id
}

\begin{abstract}
The presence of phosphate in wastewaters can cause eutrophication of surface water bodies leading to algal-blooming in the aquatic environment and degradation of water quality. Phosphate removal from wastewaters by conventional biological treatment removes only $10-30 \%$ of the phosphate, whilst chemical treatment using precipitants such as calcium or iron salts, although effective, is expensive and produces water-rich sludge which must be further treated. Hence, phosphate removal by adsorption in the form of Ca-phosphate has been proposed as an alternative to the more traditional methods. This study investigated the feasibility of using dolomite-a common sedimentary rock-from Padalarang, West Java, Indonesia as the adsorbent for the removal of phosphate from synthetic aqueous solution. Chemical analysis revealed that the Padalarang dolomite contains 33.6-36.2\% $\mathrm{CaO}$. Batch experiments at room temperature indicated that optimum removal of phosphate was achieved at $\mathrm{pH} 9$. At $25^{\circ} \mathrm{C}$, where increasing concentrations of phosphate $(10-100 \mathrm{mg} / \mathrm{L})$ increased phosphate adsorption (2.15-31.3 $\mathrm{mg} / \mathrm{g})$ by the dolomite. The adsorption of phosphate could be described by the Langmuir isotherm model, with constants $\mathrm{Q}_{\mathrm{m}}=476.19 \mathrm{mg} / \mathrm{g}, \mathrm{K}_{\mathrm{L}}=0,00106 \mathrm{~L} / \mathrm{mg}$ and equilibrium parameter $\left(\mathrm{R}_{\mathrm{L}}\right): 0.904-$ 0.989. Phosphate adsorption by dolomite not only permits its removal but also its potential recovery for reuse.
\end{abstract}

Keywords: adsorption; dolomite; Langmuir isotherm; phosphate removal.

\section{$1 \quad$ Introduction}

The presence of phosphorus in water bodies can be harmful to the aquatic environment as it can cause eutrophication, which in turn leads to algalblooming and a decline in water quality. The main source of phosphorus pollution in water bodies is its use in agricultural and industrial activities, aside from also being present in domestic wastewaters. The concentration of phosphate in municipal wastewaters may be as much as $25 \mathrm{mg} / \mathrm{L}$, whilst according to Akay, et al. [1] industrial effluents could contain concentrations of phosphate in excess of $10 \mathrm{mg} / \mathrm{L}$. Hence, in order to avoid eutrophication of natural water bodies, the phosphorus should first be removed from wastewaters before they're discharged into such water bodies. Unfortunately, conventional biological treatment removes only $10-30 \%$ of the influent phosphorus, as

Received March $25^{\text {th }}, 2014$, Revised July $8^{\text {th }}, 2014$, Accepted for publication October $13^{\text {th }}, 2014$

Copyright (C) 2014 Published by ITB Journal Publisher, ISSN: 2337-5779, DOI: 10.5614/j.eng.technol.sci.2014.46.4.5 
microbes utilize the phosphorus for cell synthesis and energy transport only [2]. Whereas, phosphate removal by chemical precipitants, although effective, is costly and produces water-rich sludge that must be further treated. Accordingly, there is a need to find alternative methods for the removal of phosphate. Recently, phosphate removal through adsorption has received increasing attention as one of the more promising alternative techniques due to its high efficiency, easy handling, the availability of different adsorbents, costeffectiveness and the capacity to regenerate and reuse solids [3,4]. The sorption reaction is governed by the physical and chemical properties of the material used as the adsorbent, of which calcium-rich materials appear to be of interest due to the strong interaction between phosphates and some $\mathrm{Ca}$ compounds. According to Chen, et al. [4] the advantages of phosphate removal by sorption include (a) the un-necessary need of precipitants; (b) avoidance of increase in the sludge volume; (c) easy dewatering of the product; and (d) potential reuse of the dehydrated product as a source of phosphorus. Song, et al. [5] further stated that formation of calcium phosphate is a good approach for phosphorus recovery as calcium phosphate is the effective composition of phosphate rocks and is thus readily accepted by the phosphate industry as a source of phosphate.

Dolomite, a common sedimentary rock-forming mineral found throughout the world has the chemical composition of $\mathrm{CaMg}\left(\mathrm{CO}_{3}\right)_{2}$; it also demonstrates properties that are very similar to those of calcite $\left(\mathrm{CaCO}_{3}\right)$ [6]. Aside from being a mineral it is also known to be a rock, with the general formula of dolomite being $\mathrm{AB}\left(\mathrm{CO}_{3}\right)_{2}$, where $\mathrm{A}$ can be calcium, barium and/or strontium and $\mathrm{B}$ can be iron, magnesium, zinc and/or manganese. The amount of calcium and magnesium in most specimens is equal but occasionally one element may be slightly greater. Small amounts of iron and manganese are also sometimes present [7]. Due to dolomite's similarity with calcite $\left(\mathrm{CaCO}_{3}\right)$, as well as being a calcium rich material, it could serve as a sorbent for the removal of phosphate from aqueous solution, by means of crystallization or precipitation of calcium phosphate on the surface of the dolomite. The dolomite would therefore serve as a seed to catalyse the crystallization/precipitation of calcium phosphate. Removal of phosphate by adsorption has previously been reported using raw and calcinated dolomite from the Erzunum region in Turkey [8], dolomite ores from Egypt [9] and half-burned dolomite [10]. According to Hanna, et al. [9] dolomite can effectively fix phosphate due to the presence of $\mathrm{Ca}^{2+}, \mathrm{Mg}^{2+}, \mathrm{Al}^{3+}$ and $\mathrm{Fe}^{2+}$ chemical species' in their chemical composition.

The objective of this study was therefore to investigate the potential use of dolomite that originates from the region of Padalarang, West Java, Indonesia, as a sorbent to remove phosphate from synthetic aqueous solution. As various physico-chemical factors affect adsorption reactions, the effect of $\mathrm{pH}$ and initial phosphate concentration on phosphate sorption were examined and the 
corresponding sorption capacity of the dolomite at optimum $\mathrm{pH}$ was determined by the appropriate adsorption isotherm model.

\section{Experiments and Methods}

\subsection{Materials}

Table 1 summarizes the chemical composition of the dolomite sample used in this study as determined by ASTM analysis. As can be seen, the major chemical species' contained in the dolomite sample are $\mathrm{Ca}$ and $\mathrm{Mg}$. The sample was first dried overnight at $105^{\circ} \mathrm{C}$, cooled, pulverized with a mortar and then sieved at 60 mesh. All prepared dolomite particles were stored in a dessicator prior to use.

A phosphate stock solution of $1000 \mathrm{mg} / \mathrm{L}$ was prepared by dissolving anhydrous $\mathrm{KH}_{2} \mathrm{PO}_{4}$ in distilled water. Varying concentrations of phosphate solution used in the batch experiments were then prepared by diluting the stock solution in tap water. The $\mathrm{Ca}^{2+}$ hardness of the tap water was $170.4 \mathrm{mg} / \mathrm{L} \mathrm{CaCO}_{3}$, whilst $\mathrm{Mg}^{2+}$ hardness was $115.9 \mathrm{mg} / \mathrm{L} \mathrm{CaCO}_{3}$. The presence of $\mathrm{Ca}$ and $\mathrm{Mg}$ in the tap water aids the precipitation of phosphate on the dolomite surface.

Table 1 Chemical composition of Padalarang dolomite sample.

\begin{tabular}{cc}
\hline Compound & $\begin{array}{c}\text { Percent Composition } \\
(\%)\end{array}$ \\
\hline $\mathrm{CaO}$ & $33.6-36.2$ \\
$\mathrm{MgO}$ & $16.46-17.53$ \\
$\mathrm{SiO}$ & $0.32-0.54$ \\
$\mathrm{Al}_{2} \mathrm{O}_{3}$ & $0.26-0.33$ \\
$\mathrm{Fe}_{2} \mathrm{O}_{3}$ & $0.16-0.22$ \\
$\mathrm{TiO}_{2}$ & $0.027-0.13$ \\
$\mathrm{~K}_{2} \mathrm{O}$ & $0.005-0.016$ \\
$\mathrm{Na}_{2} \mathrm{O}_{3}$ & $0.021-0.024$ \\
$\mathrm{LOI}$ & $45.7-45.8$ \\
$\mathrm{H}_{2} \mathrm{O}$ & $0.15-0.55$ \\
\hline
\end{tabular}

In this study, phosphate concentration was determined spectrophotometrically by the Stannous Chloride method (Standard Methods Vol. 20, 2005) using a MERCK AQ 118 Spectrophotometer at $\lambda 690 \mathrm{~nm}$, which corresponds to maximum absorbance.

\subsection{Effect of Initial pH on Phosphate Removal Efficiency}

Batch experiments were carried out in $250 \mathrm{~mL}$ Erlenmeyer flasks at room temperature. For this $0.2 \mathrm{~g}$ of the dolomite sample was mixed with $100 \mathrm{~mL}$ of $100 \mathrm{mg} / \mathrm{L}$ phosphate solution and the $\mathrm{pH}$ of the solution adjusted using 
solutions of $\mathrm{HCl}$ and $\mathrm{NaOH}$. The flasks were then shaken at $160 \mathrm{rpm}$ for 72 hours. Blanks containing no dolomite were also prepared for each $\mathrm{pH}$ assessed. At the end of the incubation period aliquots were drawn from the flasks, centrifuged for 2 minutes at $3750 \mathrm{rpm}$ and the residual phosphate concentration measured by spectrophotometry. The efficiency of phosphate removal was calculated as follows:

$$
\% \text { phosphate removal }=\frac{\left(C_{o}-C_{t}\right)}{C_{o}} \times 100 \%
$$

where $C_{o}$ is the initial phosphate concentration $(\mathrm{mg} / \mathrm{L})$ and $C_{t}$ is the remaining phosphate concentration at time $\mathrm{t}(\mathrm{mg} / \mathrm{L})$.

\subsection{Adsorption Experiments}

The batch adsorption experiments were carried out at $25^{\circ} \mathrm{C}$. For this $0.2 \mathrm{~g}$ of the pulverized dolomite sample was mixed with $100 \mathrm{~mL}$ phosphate solution of various concentrations $(10,20,30,40,50,60,70,80,90$ and $100 \mathrm{mg} / \mathrm{L})$ and the solution's $\mathrm{pH}$ was adjusted to that of the optimum $\mathrm{pH}$ value determined from the experiment described above. The mixture was then agitated at $160 \mathrm{rpm}$ in a water bath adjusted to $25^{\circ} \mathrm{C}$ and aliquots taken at pre-determined time intervals over a period of 96 hours. The aliquots were centrifuged for 2 minutes at 3750 rpm and the residual phosphate concentration measured by spectrophotometry. The amount of phosphate adsorbed by the dolomite was calculated as follows:

$$
\frac{X}{M}=\frac{\left(C_{o}-C_{t}\right) \cdot V}{M}
$$

where $\frac{X}{M}$ is the amount of phosphate adsorbed by the dolomite $(\mathrm{mg} / \mathrm{g}), V$ is the volume of the solution (L) and $M$ is amount of adsorbent $(\mathrm{g})$.

\subsection{Calculation of Adsorption Isotherms}

The isotherm equations used to determine the mechanism of phosphate adsorption by Padalarang dolomite were the Freundlich and Langmuir isotherm equations.

The Freundlich isotherm is an exponential equation that assumes that as the adsorbate concentration increases so too does the concentration of the adsorbate on the adsorbent surface [11].The mathematical expression of the Freundlich isotherm is as follows:

$$
\frac{X}{M}=K_{F} C_{e^{\frac{1}{n}}}
$$

where $K_{F}$ is a rough indicator of the adsorption capacity $(\mathrm{mg} / \mathrm{g}), 1 / n$ is the adsorption intensity and $C_{e}$ is the equilibrium liquid-phase concentration of the 
adsorbate $(\mathrm{mg} / \mathrm{L})$. The magnitude of the exponent, $1 / n$ gives an indication of the favorability of adsorption, where values of $n>1$ represent favorable adsorption conditions [12].

The Langmuir isotherm equation is based on the assumption of a monolayer coverage of adsorbate over a homogenous adsorbent, and that when equilibrium is attained no further adsorption can take place. Sorption is assumed to take place at specific homogenous sites in the adsorbent and the sorption of each molecule has equal sorption energy [13]. The theoretical Langmuir isotherm equation is as follows:

$$
\frac{X}{M}=\frac{Q_{m} K_{L} C_{e}}{1+K_{L} C_{e}}
$$

where $Q_{m}$ is the maximum amount of adsorption corresponding to complete monolayer coverage on the surface $(\mathrm{mg} / \mathrm{g})$; and $K_{L}$ is the Langmuir constant related to the energy of adsorption (L/mg). According to Hall, et al. [14] the essential features of the Langmuir adsorption isotherm is expressed by a dimensionless constant known as the separation factor or equilibrium parameter $\left(R_{L}\right)$, which is defined as follows:

$$
R_{L}=\frac{1}{1+K_{L} C_{0}}
$$

The $R_{L}$ indicates the shape of the isotherm to be either irreversible $\left(R_{L}=0\right)$, favorable $\left(0<R_{L}<1\right)$, linear $\left(R_{L}=1\right)$ or unfavorable $\left(R_{L}>1\right)$ to adsorption.

\section{$3 \quad$ Results and Discussions}

\subsection{Effect of Initial pH on Phosphate Removal Efficiency}

Figure 1 shows the effect of initial $\mathrm{pH}$ on phosphate removal efficiency by Padalarang dolomite after 72 hours of incubation at room temperature. As shown in Figure 1, phosphate removal efficiency of $100 \mathrm{mg} / \mathrm{L}$ phosphate by dolomite was slightly lower at acidic $\mathrm{pH}$ values than that at alkaline conditions, with phosphate removal reaching a maximum value of about $62.8 \%$ at $\mathrm{pH} 9$. These results can be explained both by the dissolution of $\mathrm{Ca}^{2+}$ ions from the dolomite and the polyprotonated nature of phosphate in solution. It is known that $\mathrm{H}_{2} \mathrm{PO}_{4}{ }^{-}$and $\mathrm{HPO}_{4}{ }^{2-}$ species are dominant when the $\mathrm{pH}$ solution is between 5 $-10, \mathrm{H}_{2} \mathrm{PO}_{4}^{-}$species is dominant at a $\mathrm{pH}$ of below $7, \mathrm{HPO}_{4}{ }^{2-}$ predominates at $\mathrm{pH}$ values between 7 and 10 , and $\mathrm{PO}_{4}{ }^{3-}$ species dominates at a $\mathrm{pH}$ of 12,5 and higher [15]. Hence, in this experiment the dominant protonated species at $\mathrm{pH} 9$ is $\mathrm{HPO}_{4}^{2-}$, which is assumed to increase the probability of phosphate precipitation based on the reaction:

$$
\mathrm{Ca}^{2+}+\mathrm{HPO}_{4}^{2-}=\mathrm{CaHPO}_{4}
$$


Figure 1 also indicates some slight phosphate removal (about 3.7 - 5.3\%) occuring in the blank experiments, with the largest removal occuring at $\mathrm{pH}$ values of 9 and 10 . Given that the experiments were conducted with a phosphate solution made up in tap water with a Ca hardness of $170.4 \mathrm{mg} / \mathrm{L}$ $\mathrm{CaCO}_{3}$ and $\mathrm{Mg}^{2+}$ hardness of $115.9 \mathrm{mg} / \mathrm{L} \mathrm{CaCO}$, it is conjectured that phosphate removal in the blank solutions are due to the precipitation of $\mathrm{Ca}$ phosphate and Mg-phosphate compounds.

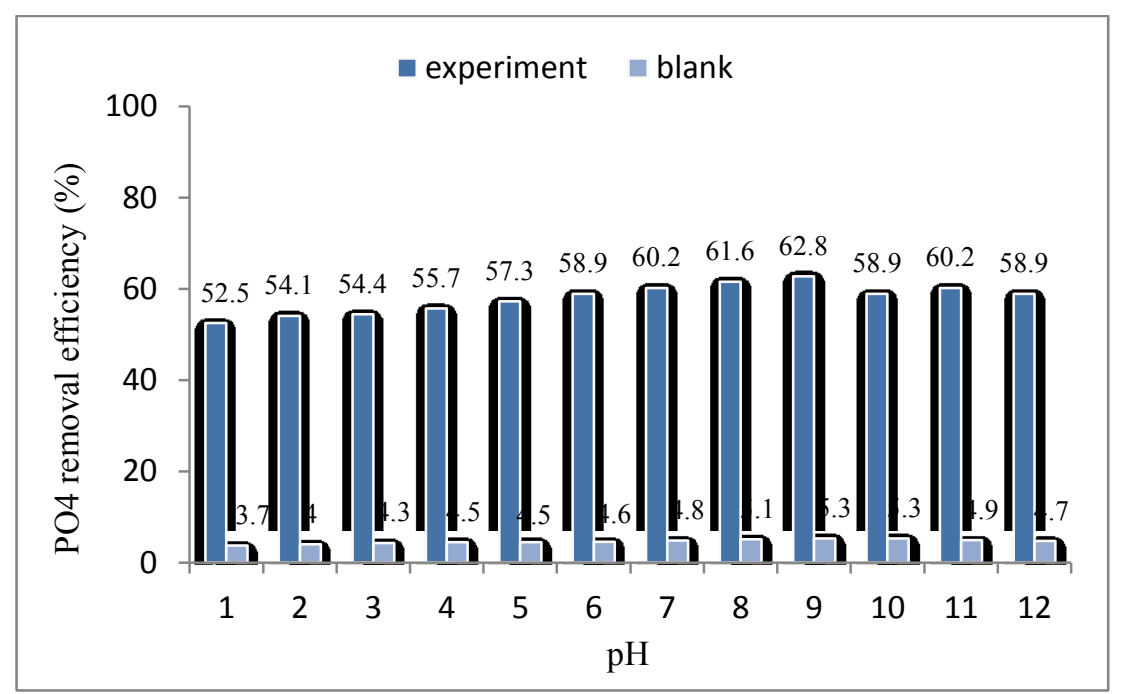

Figure 1 Effect of $\mathrm{pH}$ on phosphate removal efficiency, $\mathrm{C}_{0}=100 \mathrm{mg} / \mathrm{L} \mathrm{PO}_{4}$, room temperature.

\subsection{Adsorption Experiments}

Batch adsorption experiments with various concentrations of phosphate (10-100 $\mathrm{mg} / \mathrm{L}$ ) were conducted at the optimum $\mathrm{pH}$ value of 9 and $25^{\circ} \mathrm{C}$ temperature. As shown in Figure 2, the largest phosphate adsorption $(\mathrm{mg} / \mathrm{L})$ was obtained at 100 $\mathrm{mg} / \mathrm{L}$ phosphate, whilst the lowest adsorption was obtained at $10 \mathrm{mg} / \mathrm{L}$ of phosphate. Hence, the amount of phosphate adsorbed on the dolomite increased with increasing concentrations of phosphate, which indicates that Padalarang dolomite has an affinity for the phosphate. An increase in phosphate concentration increased the driving force of the phosphate in order to overcome mass transfer resistance of the phosphate between the aqueous and solid phases, which in turn cause more phosphate being adsorbed by the dolomite.

In order to optimize the design of an adsorption process for the removal of phosphate from solution it is important to establish the appropriate adsorption mechanism. This mechanism can be determined using adsorption isotherm 
equations at a constant temperature. Among the various isotherm equations frequently used to determine the mechanism of phosphate adsorption are the Freundlich and Langmuir isotherm models. Hence, the results of the batch adsorption experiments were plotted against the Freundlich and Langmuir equations. Table 2 presents the results obtained from this exercise.

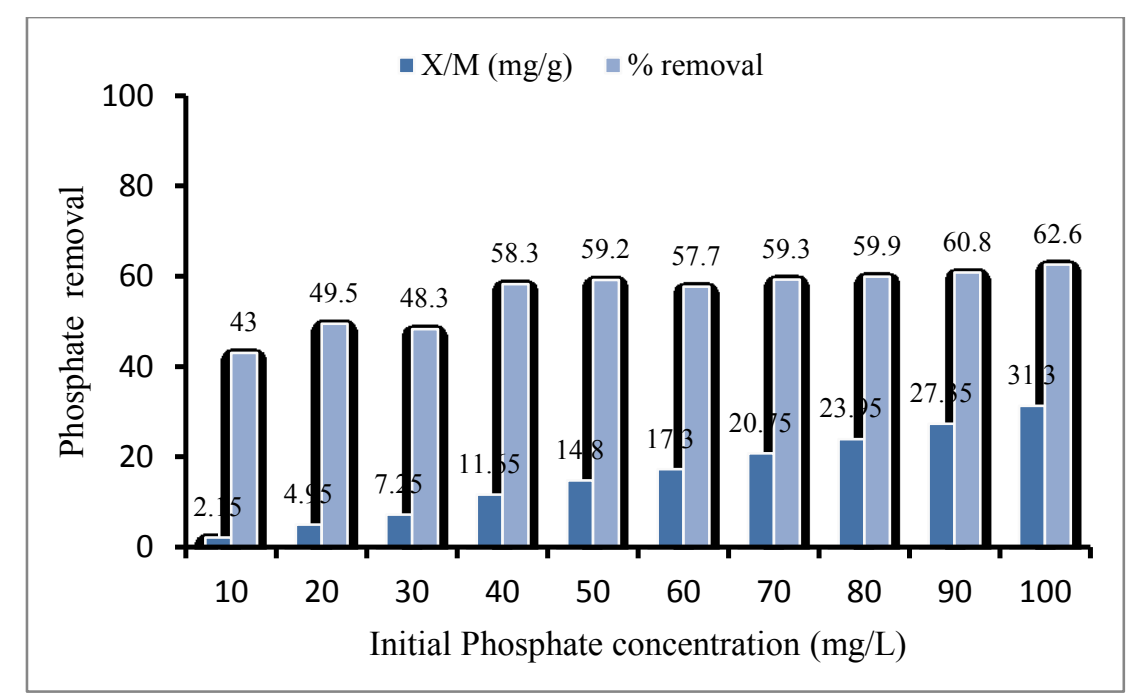

Figure 2 Phosphate adsorption on Padalarang dolomite at various concentrations of phosphate, $\mathrm{pH} 9,25^{\circ} \mathrm{C}$.

Table 2 Parameters and regression coefficients $\left(\mathrm{R}^{2}\right)$ of Freundlich and Langmuir isotherm equations describing phosphate adsorption on Padalarang dolomite.

\begin{tabular}{ccc|ccc}
\hline \multicolumn{3}{c|}{ Freundlich isotherm } & \multicolumn{3}{c}{ Langmuir isotherm } \\
\hline $\mathbf{n}$ & $\mathbf{K}_{\mathbf{F}} \mathbf{( m g / g )}$ & $\mathbf{R}^{\mathbf{2}}$ & $\mathbf{Q}_{\mathbf{m}} \mathbf{( m g / g )}$ & $\mathbf{K}_{\mathbf{L}}(\mathbf{L} / \mathbf{m g})$ & $\mathbf{R}^{\mathbf{2}}$ \\
\hline 0.998 & 0.497 & 1 & 476.19 & 0.00106 & 0.9997 \\
\hline
\end{tabular}

The regression coefficients given in Table 2 suggest that phosphate adsorption on Padalarang dolomite can be described by both the Freundlich and Langmuir isotherms, with the $\mathrm{R}^{2}$ of the Freundlich equation being slightly higher than that of the Langmuir equation. However on closer scrutiny, the $\mathrm{n}$ of the Freundlich equation is still below 1 (i.e. 0.9997), whilst conditions that are favorable for adsorption are represented by values of $n>1$ [12]. What's more, a value of $n<1$ indicates that P-removal to the solids are not preferential and spontaneous [15]. Accordingly, the Langmuir model is believed to be a better model to describe the adsorption mechanism of phosphate on pulverized and sieved Padalarang dolomite. Based on the Langmuir equation the $Q_{m}$ is $476.19 \mathrm{mg} / \mathrm{g}$ and $K_{L}$ is $0.00106 \mathrm{~L} / \mathrm{mg}$ (Table 2). What's more, calculation of the $R_{L}$ from the Langmuir 
model ranged from $0.904-0.989$ (Table 3), indicating that the adsorption process of phosphate on dolomite was a favorable process [14].

Table $3 \mathrm{R}_{\mathrm{L}}$ of Langmuir model of phosphate adsorption on Padalarang dolomite.

\begin{tabular}{cc|cc}
\hline $\mathbf{C}_{\mathbf{0}}(\mathbf{m g} / \mathbf{L})$ & $\mathbf{R}_{\mathbf{L}}$ & $\mathbf{C}_{\mathbf{0}}(\mathbf{m g} / \mathbf{L})$ & $\mathbf{R}_{\mathbf{L}}$ \\
\hline 10 & 0.989 & 60 & 0.94 \\
20 & 0.979 & 70 & 0.931 \\
30 & 0.969 & 80 & 0.922 \\
40 & 0.959 & 90 & 0.913 \\
50 & 0.949 & 100 & 0.904 \\
\hline
\end{tabular}

Evidence of adsorption occuring on the dolomite is given in Figure 3, which shows SEM photography analysis of a raw dolomite particle and a dolomite particle after 96 hours of contact with a $100 \mathrm{mg} / \mathrm{L}$ solution of phosphate at $\mathrm{pH} 9$ and $25^{\circ} \mathrm{C}$. As shown in Figure 3, the raw dolomite particle is smaller in diameter $(5 \mu \mathrm{m}$ scale) than that which has been in contact with the phosphate solution $(10 \mu \mathrm{m}$ scale), due to the formation of a precipitate on the surface of the dolomite particle.

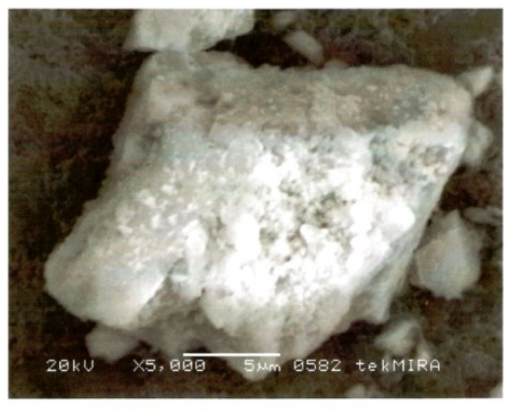

(a) Raw dolomite particle, $5000 \mathrm{X}$

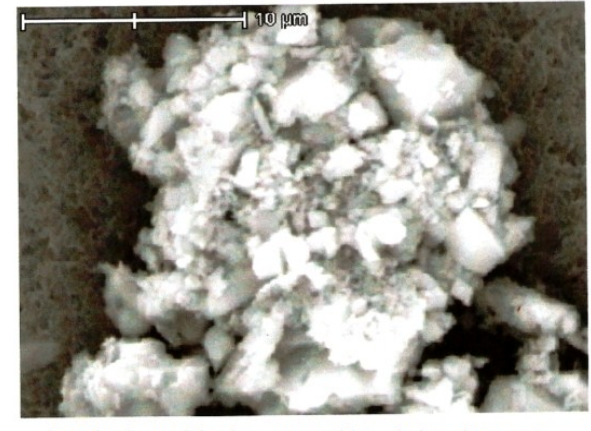

(b) Dolomite particle after contact with a solution of $100 \mathrm{mg} / \mathrm{L}$ phosphate, $5000 \mathrm{X}$

Figure 3 SEM photography analysis of raw dolomite and dolomite contacted with a solution of $100 \mathrm{mg} / \mathrm{L}$ phosphate for 96 hours, $\mathrm{pH} 9,25^{\circ} \mathrm{C}$.

Roques, et al. [10] in their study on phosphate removal using half-burned dolomite also observed a precipitate on the surface of the half-burned dolomite grains, which by ESCA analysis appeared to be an amorphous nonstoichiometric badly crystallized compound of calcium phosphate, which conforms to the fact that the thermodynamically stable form of calcium phosphate - i.e. hydroxyapatite, $\mathrm{Ca}_{10}\left(\mathrm{PO}_{4}\right)_{6}(\mathrm{OH})_{2}$,- never precipitates directly in solution, but forms after the recrystallization of precursors such as $\mathrm{CaHPO}_{4}$ [16]. Roques, et al. [10] also reported that the fixed phosphate could be 
liberated from the half-burned dolomite with solutions of $\mathrm{HCl}$ and sodiumacetate, thus indicating the possible recovery of the phosphate. Another method for phosphate recovery is achieved by de-watering of the precipitated or crystallized product, which could be attained by either atmospheric drying or by plate pressing of the hydrated product. It is believed that the dehydrated product could be directly used as phosphorus fertilizer or as an intermediate for formulation of fertilizer products intended for agriculture activities. What's more, the dehydrated product might also serve as raw material for the production of phosphoric acid.

\section{Conclusions}

Phosphate removal was achieved in batch experiments by mixing a solution containing phosphate with pulverized Padalarang dolomite particles of 60 size mesh. The greatest phosphate removal efficiency in a $100 \mathrm{mg} / \mathrm{L}$ solution of phosphate occurred at a $\mathrm{pH}$ value of $9(62.8 \%)$. Batch experiments were conducted with various phosphate solution concentrations $(10-100 \mathrm{mg} / \mathrm{L}), \mathrm{pH} 9$ with a $25^{\circ} \mathrm{C}$ temperature,which demonstrated that increasing concentrations of phosphate increased phosphate sorption by Padalarang dolomite (2.15-31.3 $\mathrm{mg} / \mathrm{g}$ ), indicating that Padalarang dolomite has an affinity for phosphate. ASEM analysis of the dolomite particle mixed with phosphate solution showed the presence of a superficial precipitate on the treated dolomite particles, which is assumed to be amorphous $\mathrm{CaHPO}_{4}$. Further precipitate identification could be done by X-ray diffraction or Infra Red adsorption techniques to confirm this assumption. Although both the Freundlich and Langmuir isotherm models appear to describe the sorption mechanism of phosphate on Padalarang dolomite, it appears that the Langmuir model is a better model to describe the sorption process, with the Langmuir parameters being $\mathrm{Q}_{\mathrm{m}}=476.19 \mathrm{mg} / \mathrm{g}$ and $\mathrm{K}_{\mathrm{L}}=0.00106 \mathrm{~L} / \mathrm{mg}$, with $\mathrm{R}_{\mathrm{L}}$ values of $0.904-0.989$. Given the small sorption energy, it is conjectured that the phosphate could be liberated from the dolomite, which would permit its potential recovery and reuse.

\section{$5 \quad$ References}

[1] Akay, G., Keskinler, B., Cakici, A. \& Danis, U., Phosphate Removal from Water by Red Mud Using Crossflow Microfiltration, Water Res., 32, pp. 717-726, 1998.

[2] Can, M.Y. \& Yildiz, E., Phosphate Removal from Water by Flyash: Factorial Experimental Design, J. Hazard. Mater., B135, pp. 165-170, 2006.

[3] Zhang, J., Shen, Z., Shan, W., Mei, Z. \& Wang, W., Adsorption Behavior of Phosphate on Lanthanum(III)-Coordinated Diamino-Functionalized 
3D Hybrid Mesoporous Silicates Material, J. Hazard. Mater., 186, pp. 7683, 2011.

[4] Chen, X., Kong, H., Wu, D., Wang, X. \& Lin, Y., Phosphate Removal and Recovery through Crystallization of Hydroxyapatite Using Xonotlite as Seed Crystal, J. Environ. Sci., 21, pp. 575-580, 2009.

[5] Song, Y., Weidler, P.G., Berg, U, Nüesch, R. \& Donnert, D., CalciteSeeded Crustallization of Calcium Phosphate for Phosphorus Recovery, Chemosphere, 63, pp. 236-243, 2006.

[6] Karaca, S., Gürses, A., Ejder, M. \& Açikyildiz., Kinetic Modeling of Liquid-Phase Adsorption of Phosphate on Dolomite, J. Colloid Interface Sci., 277, pp. 257-263, 2004.

[7] Walker, G.M., Hansen, L., Hanna, J.A. \& Allen, S.J, Kinetics of a Reactive Dye Adsorption onto Dolomitic Sorbents, Water Res., 37, pp. 2081-2089, 2003.

[8] Karaca, S., Gürses, A., Ejder, M. \& Açikyildiz., Adsorptive Removal of Phosphate from Aqueous Solutions Using Raw and Calcinated Dolomite, J. Hazard. Mater., B128, pp. 273-279, 2006.

[9] Hanna, A.A., Sherief, M.A. \& Abo Elenin, R.M.M., Phosphate Removal from Wastewater by Calcite and Dolomite Ores, Phosphorus Res. Bull., 22, pp. 7-12, 2008.

[10] Roques, H., Nugroho-Jeudy, L. \& Lebugle, A., Phosphorus Removal from Wastewater by Half-Burned Dolomite, Water Res., 25 (8), pp. 959965, 1991.

[11] Freundlich, H., Adsorption in Solution, Phys. Chemie, 57, pp. 384-410, 1906.

[12] Malik, P.K., Dye Removal from Wastewater Using Activated Carbon Developed from Sawdust: Adsorption Equilibrium and Kinetics, J. Hazard. Mater., B113, pp. 81-88, 2004.

[13] Langmuir, I., Adsorption of Gases on Plane Surfaces of Glass, Mica and Platinum., J. Am. Chem. Soc., 40, pp. 1361-1403, 1918.

[14] Hall, K.R., Eagleton, L.C., Acrivos, A. \& Vermeulen, T., Pore and Solid Diffusion Kinetics in Fixed Bed Adsorption Under Constant Pattern Conditions., ind. Eng. Chem. Fundamentals, 5(2), pp. 212-223, 1966.

[15] Chen, J., Cai, Y., Clark, M. \& Yu, Y., Equilibrium and Kinetic Studies of Phosphate Removal from Solution onto A Hydrothermally Modified Oyster Shell Material, PLOS One, 8(4), pp. 1-10, 2013.

[16] House, W.A., The Physico-Chemical Conditions for The Precipitation of Phosphate with Calcium, Environ. Technol., 20, pp. 727-733, 1999. 